\title{
交通事故に着目した救急医療サービスの評価に関する基礎的研究*
}

\section{A Study on Evaluation of Emergency Medical Service considering Traffic Accidents*}

二神 透**, 大野訓 ${ }^{* * *}$, 柏谷増男 ${ }^{* * * *}$

by Tohru FUTAGAMI, Jun OONO, Masuo KASHIWADANI

\section{1.はじめに}

近年，自動車交通の増加に伴い交通事故件数も増 加の傾向をたどってきている。その結果，交通事故 による死亡者の数も増加の傾向にあり社会的な問題 となっている。この問題に対して，日本でも救急救 命士制度の導入が 1991 年に始まっている。しかし， その後の学会の調査によると導入後も呼吸や心臓が 停止した患者の蘇生率は向上していない事が明らか になった。一般に, 救急医療のサービス指標は, 救 急指定病院までの搬送時間が用いられる。本研究で は, 多量出血患者の治療時間と死亡率の関係より 15 分をサービス指標として用いる ${ }^{1)}$ 。ドイツではいか に早く患者の手当を行うか，救急医療の目的はその 一点に注がれている。そのために，ヘリコプターの 導入がなされ，交通事故死者数 1971年の指数を 100 とすれば 1987 年時点で $40 \%$ 弱まで減少している ${ }^{2) 。 ~}$ しかし，日本の地方都市レベルにおいて，現実的に ヘリコプターを導入することは, 過密市街地でのへ リポートの設備や財政面等など問題が多い。そこで 地方都市においては，適切に救急告示病院を指定す るとともに, 救急車両をいかにスムーズに運行させ, サービス時間の短縮化を図っていくかが当面の課題 であろう。

本研究では上述した問題に着目し，はじめに，松 山市域の交通事故を対象に救急医療サービスについ ての現状分析を行う。具体的には，ネットワークモ

*キーワーズ : 地域計画, 救急医療サービス

**正会員 学博 愛媛大学講師 工学部環境建設工学科

（松山市文京町 3 番, TEL089-927-9837, FAX089-927-9837）

***学生員 愛媛大学大学院理工学研究科土木海洋工学専攻

(同上)

フェロー 工博 愛媛大学教授 工学部環境建設工学科

（松山市文京町 3 番, TEL089-927-9825, FAX089-927-9843）
デルを用いて，救急車両が走行するリンクと消防 署・救急告示病院施設をノードで与える。つぎに, 交通事故は交差点付近で多発すると仮定し, 救急車 両は交通事故発生ノードに対して最短時間の消防署 から出動して, 最短時間の救急告示病院へ搬送する としてモデル化を行う。そして，現在，曜日単位の グループで指定されている ${ }^{3)}$ 救急告示病院のサービ ス水準 (15 分以内に搬送可能な交差点のカバー率)， 平均搬送時間, 搬送分担比率についての分析を行う。 ここで, 各グループの平均搬送時間を算定する際に, 救急車両の出動頻度を考慮するために，松山市の交 通事故発生場所デー夕を用いて，近似的ではあるが 交差点に交通事故確率を与えている。

以上の分析を基礎に救急告示病院（18 個）につい て，1グループを 3 病院のユニットとして, MCLP (Maximal Covering Location Problem) ${ }^{4)}$ を用い て最適施設配置についての検討を行う。さらに，市 域全体のサービスの公平性を確保するために，消防 施設をも含めた LSCP(Location Set Covering Problem) ${ }^{4)}$ について検討する。最後に, 救急車の道 路走行性の改善とサービス水準の関係について, 若 干の考察と今後の課題を整理する。

\section{2. 松山市の救急医療の現状分析}

\section{（1）救急車両の出動状況とネットワークデータ}

松山市は, 1999 年において人口 46 万人の地方中 核都市である。図 1 は, 松山市の道路ネットワーク と，消防施設，救急医療施設の配置を表している。 図中右上については，波線の円で囲まれている中心 市街地の拡大図を表している。また, 図中の数值は, 救急告示病院のノード番号を表している。松山市の 道路網の特徴は, 中心市街地でグリッド状, 郊外に 向けて放射状となっており, 近年, 環状道路が整備 されつつある。図 1 より，消防施設は，管轄おきに 


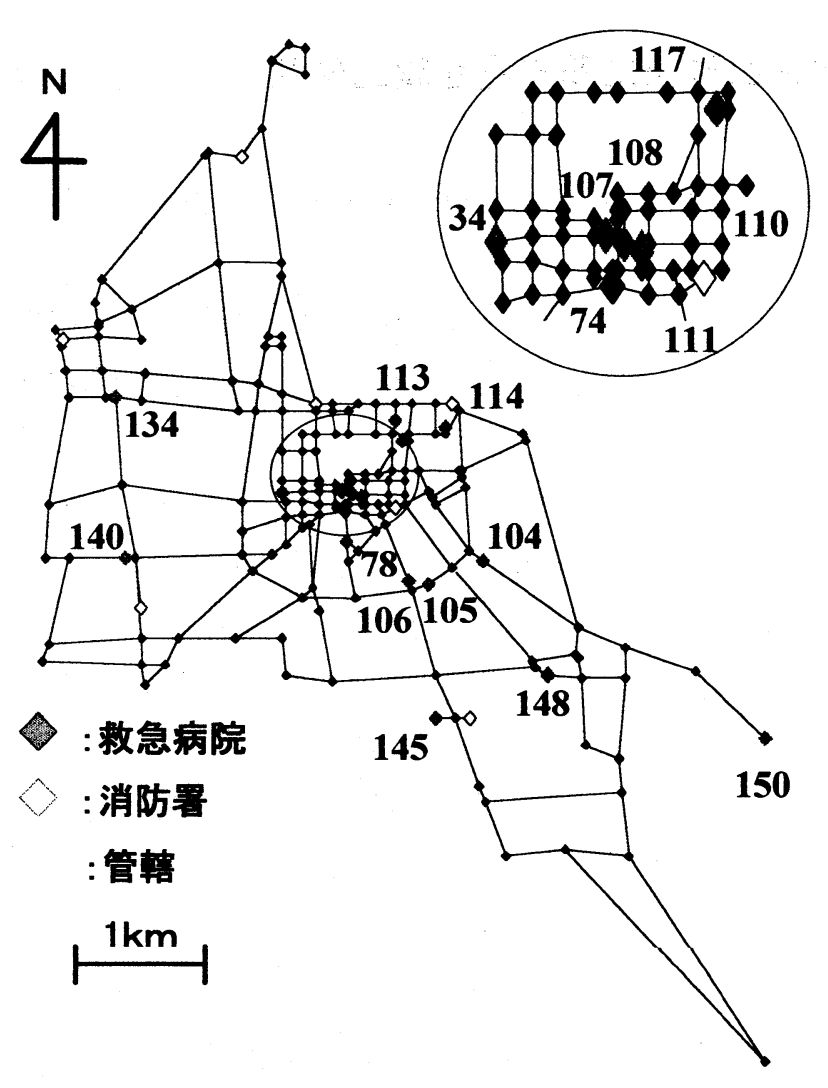

図 1 松山市の救急医療体制

比較的分散して配置されているのに対して, 救急告 示病院は中心市街地に集中していることが分かる。 ちなみに，市内には，7つの消防施設があり 7 台の 救急車 (内 2 台は高規格救急車) と 2 台の救急予備 車が装備されている。平成 9 年の松山市消防年報 ${ }^{3)}$ によると, 年間の出動件数は, 約 12,000 件強である。 一日当たりの, 平均出動回数は， 34 件である。ここ で，交通事故に着目すると，年間 3,300 件弱で，全 体の $28 \%$ を占めている。

図 2 は，愛媛県警察本部 交通部交通企画課 事故 分析・統計課より頂いた平成 10 年 4 月から平成 11 年 8 月までの約 4000 件の時間帯別交通事故発生件数 を表している。この図より, 交通事故のピークは通 勤時の午前 8〜 9 時と, 午後 $5 \sim 6$ 時であることが分 かる。当然, この時間帯は交通量も多く, 道路によ っては交通混雑のため救急車の走行に支障を来すこ とが予想される。つぎに，前述した約 4,000 件の事 故発生現場のデータを GIS 上にプロットしたものを 図 3 に示す。図上では, 構成した幹線道路で囲まれ た住宅地の細街路等に多くの事故現場が存在するよ うに見える。しかし，リンク上で発生した交通事故 が多くの地点で重なっているため, 図 1 のネットワ 一ク上以外の発生件数は, 全体の $20 \%$ 弱となって

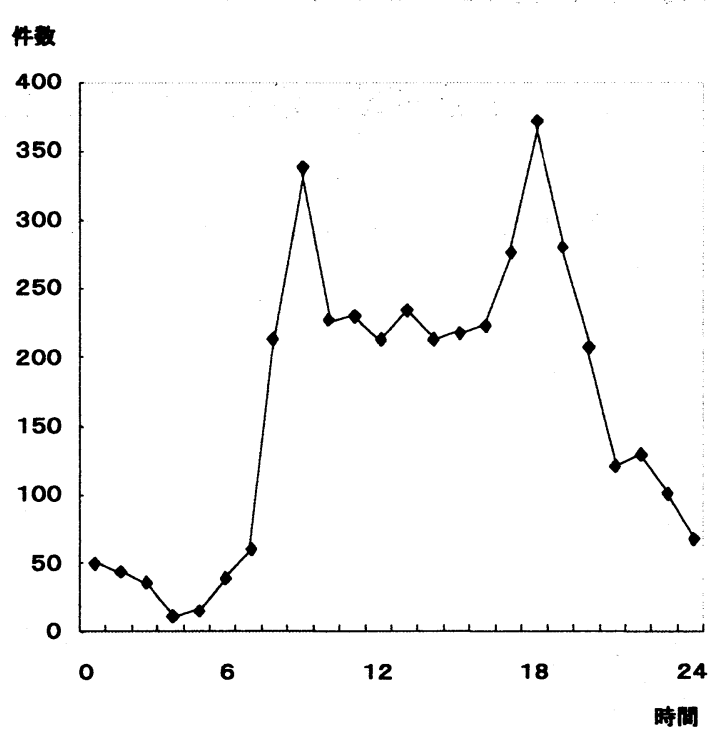

図 2 時間帯別交通事故発生件数

いる。これらの現場は, GIS 上で位置座標, 住所, 日時の項目をデータベース化しているため, クエリ 一をかけることにより，曜日別の事故の分布や，時 間帯ごとの事故の分布などを瞬時に地図上に表示す ることが可能である。紙面の制約上割愛するが，曜 日別の空間分布に着目すると, 日曜日 ・休日の事故 数は平日に比へ，約 $65 \%$ 程度の頻度となっている。 一方，平日では，事故発生の場所・頻度に大きな差 異はないことが分かった。

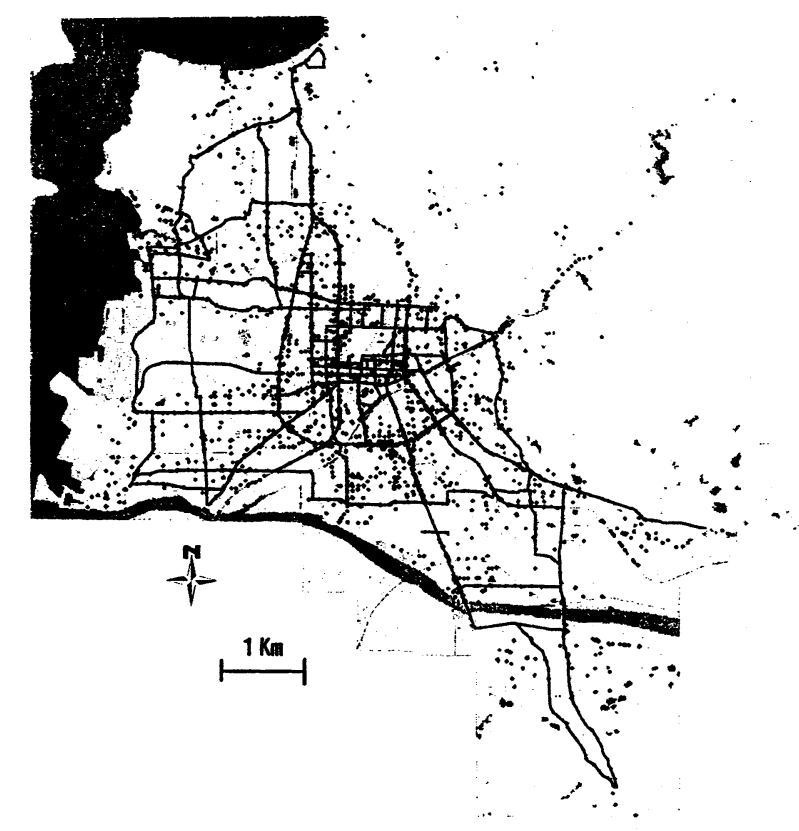

図 3 松山市の交通事故発生現場の分布

ここで，問題となるのが救急車両の実走時間の想 定と交通事故の発生頻度の取り扱いである。前者に ついて，著者らは十分なデータ及び知見を得ていな い。そこで, 本研究では, 1998 年の松山市交通セン 
サスデータを用いて時間帯別の車両速度を各リンク に与えた。そして，交通事故患者の搬送は特に緊急 性を要するため，サービス水準の評価に用いる救急 車両の速度は，逆に最も救急車両の速度が遅くなる と推測される混雑時の時間帯（午後 5 時）の車両速 度を与えることにする。また，前述したように交通 事故は, 用いたネットワーク上の $80 \%$ 強で発生して いる。しかも，比較的交差点付近に集中する傾向が 見られるため，それらを最も近接するノードへ集約 した。ネットワーク上以外で発生した交通事故につ いても同様の処理を行った。これらの值を用いて， 近似的ではあるが，各交差点における交通事故確率 と定義する。

\section{（2）救急告示病院の指定とサービス水準}

松山市は, 図 1 に示した 18 の救急告示病院を, 表 1 に示すように，曜日毎に 7 つのグループで運用し ている。本節では，（1）で想定した道路の走行速度 の基で, 現在のグループ毎のサービス水準について, 以下の 3 点から評価を行う。

\section{表 1 救急告示病院の運用体制}

\begin{tabular}{|c|c|}
\hline グループ & 救急病院 \\
\hline A & $74,105,114$ \\
\hline B & 78,108 \\
\hline C & $107,134,148$ \\
\hline D & 113,140 \\
\hline$E$ & $106,111,150$ \\
\hline F & 34,110 \\
\hline$G$ & $104,117,145$ \\
\hline
\end{tabular}

1) 15 分内搬送カバー領域

2) 平均搬送時間

3) 告示病院の搬送比率

ただし，ここでの搬送条件は，事故現場から最も 近い消防署より救急車が出発し, 最も近い告示病院 へ搬送する直近法によるものである。

はじめに，搬送時間の目安となる 15 分（現場駆け つけ時間十処置時間十病院までの搬送時間）を制約 条件として, 各グループについてカバー率（全ノー ド数に占めるカバーノード数）の算定を行った。ち なみに，処置時間とは松山市の交通事故の平均現場
到着時間，平均収容所要時間等の実データより得ら れた平均処置時間（5分）を意味している。表 2 に それらの算定結果を示す。その結果，最もカバー率 が高いグループは，Cグループの $70.2 \%$ ，最も低い グループはG グループで $46.6 \%$ となり, グループ間 でサービス水準り格差が大きいことが分かる。ここ で，表 1 のCグループ，Gグループの配置パターン とカバーノードの空間特性の比較を行うために, 図 4，5にカバー領域を太線で示す。図 4 より，Cグ ループの場合, 救急告示病院が, 中心部に 1 つ, 北 西部，南東部にそれぞれ 1 つ配置され，特に北西部 の施設によるカバー率が高いことが分かる。一方， Gグループの場合，2つの施設が市街地中心部に, 1 つの施設が南部に配置されているため, 北西部の力 バ一率が低く，全体的にもカバーされていない状況 が容易に理解できる。

\section{表 2 各グループのカバー率（15 分以内）}

\begin{tabular}{|c|c|c|}
\hline グループ & 順位 & カバー率(\%) \\
\hline $\mathrm{A}$ & 2 & 57.1 \\
$\mathrm{~B}$ & 6 & 48.7 \\
$\mathrm{C}$ & 1 & 70.2 \\
$\mathrm{D}$ & 2 & 57.1 \\
$\mathrm{E}$ & 5 & 50.3 \\
$\mathrm{~F}$ & 4 & 54.5 \\
$\mathrm{G}$ & 7 & 46.6 \\
\hline
\end{tabular}

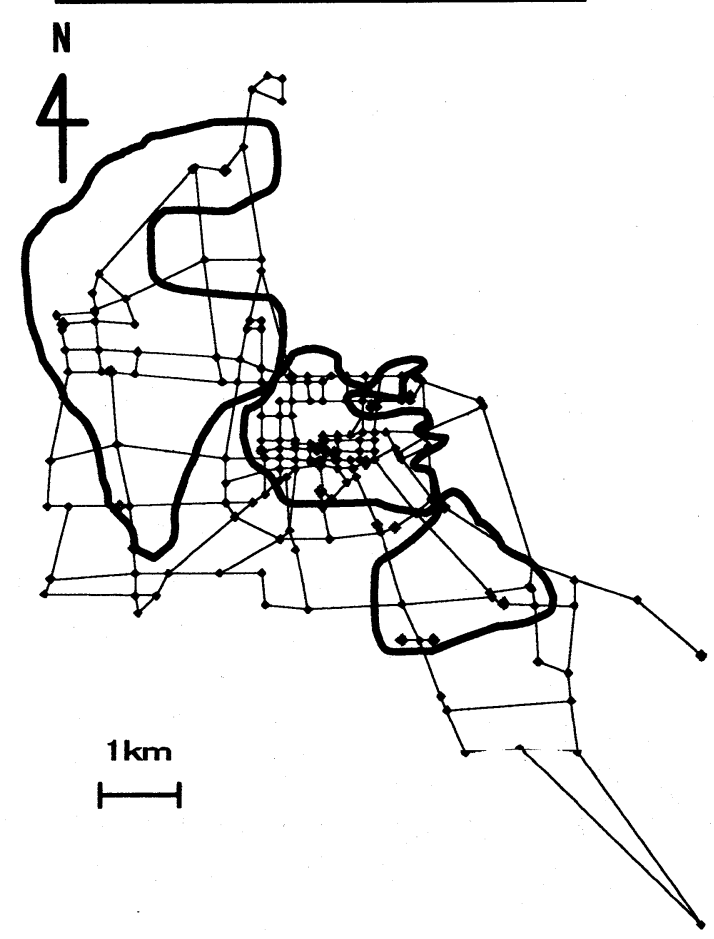

図 4 グループCによるカバー領域 


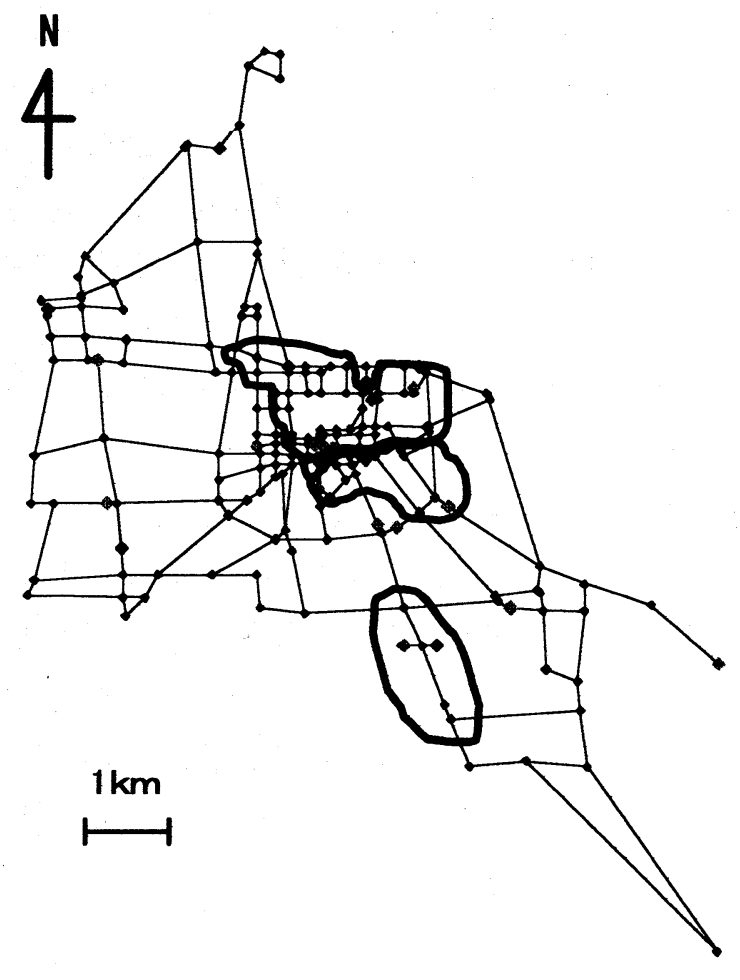

図 5 グループGによるカバー領域

つぎに, 交差点での事故確率が一定の場合と, 2 . の（1）で述べた事故確率を与えた場合の各グループ の平均搬送時間をそれぞれ算定した。それらの結果 を表 2 , 表 3 に示す。これらの結果より, 事故確率 を考慮しない場合は, 最も搬送時間の速いグループ はCであり, 最も遅いグループは $\mathrm{G}$ となり, それら の間には 2 分 30 秒の格差が生じている。そして, C グループの搬送時間は, その他のグループと比較し ても卓越して小さいことが分かる。つぎに, 事故確 率を与えた場合, 最も搬送時間の速いグループはや はりCであるが, 前者より 1 分半ほど遅くなってい る。一方, 最も遅いグループはDとなり, それらの 時間差は約 2 分となり, 前者より 30 秒短縮している。 しかし，等確率よりも実確率を用いると，すべての グループにおいて前者より 30 秒以上遅れる結果な っている。この理由は, 現況の消防施設および 18 の救急告示病院から離れた地点で交通事故が集中的 に発生していることによると考えられる。

つぎに, 全てのグループについて, 各交差点で発 生した交通事故に対する各搬送時間を算定した。そ

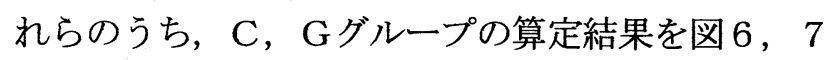
にそれぞれ示す。図6より，Cグループは，10 分, 13 分に頻度のピークがあること, また 35 分も時間

\section{表 3 平均搬送時間（等確率）}

\begin{tabular}{|c|c|c|}
\hline グルーブ & 順位 & 平均搬送時間(分) \\
\hline A & 2 & 15.5 \\
B & 6 & 15.9 \\
C & 1 & 13.5 \\
D & 5 & 15.8 \\
E & 2 & 15.5 \\
F & 4 & 15.7 \\
G & 7 & 16.0 \\
\hline
\end{tabular}

\section{表 4 平均搬送時間（実確率）}

\begin{tabular}{|c|c|c|}
\hline グループ & 順位 & 平均搬送時間(分) \\
\hline A & 2 & 16.1 \\
B & 6 & 16.9 \\
C & 1 & 15.0 \\
D & 7 & 17.1 \\
E & 2 & 16.1 \\
F & 5 & 16.8 \\
G & 4 & 16.7 \\
\hline
\end{tabular}

を要する交差点が存在していることが分かる。一方, Gグループでは, 12 分, 14 分, そして 19 分にもピ 一クがあり，また， 25 分以上の時間を要する交差点 が 13 個存在している。

最後に，搬入施設である救急告示病院の分担公平 性に着目し，各グループについて，救急告示病院へ の搬送分担率の算定を行った。その結果, 図8に示 すように，Cグループでは，搬送分担率が比較的分 散しているのに対して，E， Gグループでは，特定 の告示病院に集中することが分かる。特に，Eグル 一プでは，3つの救急告示病院の 1 つに $84.3 \%$ 集中 している。図1で，Eグループの配置パターンを確 認すると, 市街地中心部に 1 つ, 南部に 1 つ, 南東 部末端に 1 つとなり，中心部に位置する施設のみが 北側の地域のほとんどを分担しなければならないこ とが分かる。

以上より，上述した 3 つの視点から松山市の救急 医療の問題点を整理する乞，救急告示病院の配置パ ターンによって平均搬送時間に格差があり, 長時間 の搬送時間を要する交差点が存在する。また，各グ ループで時間内カバー率の格差や, 告示病院間での 分担割合の格差が大きいことが明らかになった。 


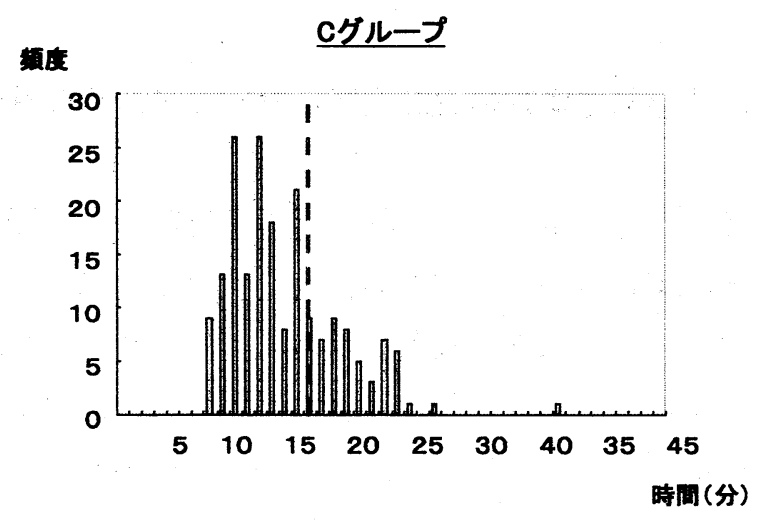

図 6 搬送時間の分布 (Cグループ)

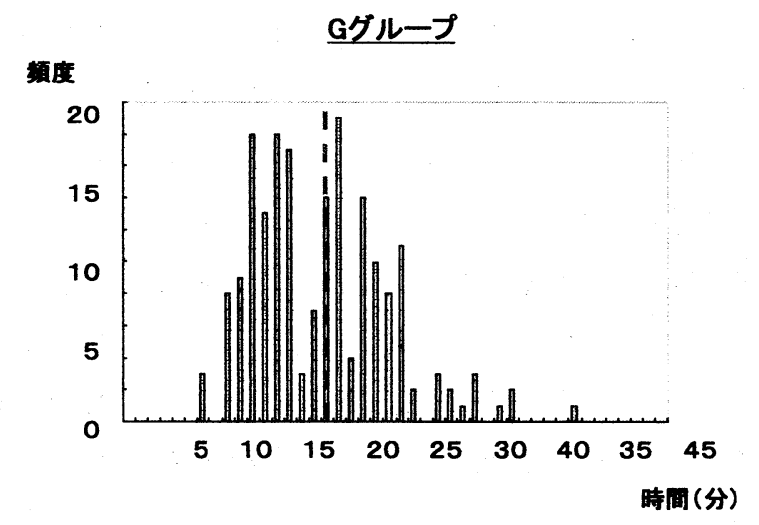

図 7 搬送時間の分布（Gグループ）

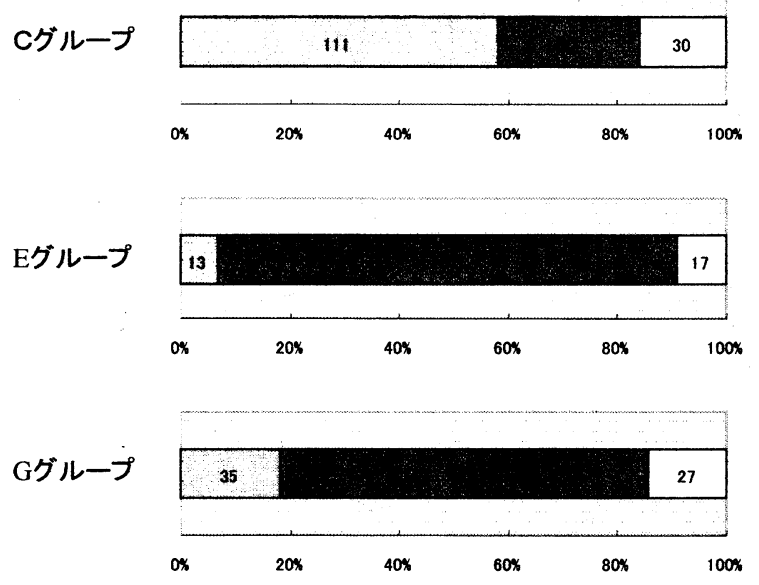

図 8 救急告示病院の分担率

\section{3．施設配置によるサービス水準の確保}

\section{（1）既存救急告示病院の最適配置}

松山市の場合, 現在の運用体制のもとでは, 市内 全域の交差点に対して, 15 分以内の搬送を確保する ことは困難であることが明らかになった。現状のグ ループの体制下では, カバー率の最大值は $70.2 \% に$ すぎない。そこで, 本節では, 既存の 18 の救急告示
病院について，カバー率を最大とする病院の再配置 について MCLP からのアプローチを試みる。

はじめに, 現在の消防施設を固定し 18 の救急病院 の候補地から, 最適な 3 つの病院の再配置を考える。 この問題は，施設数を固定 ( 3 個)，移動時間を制約 （15 分）とした MCLP として定式化される。算定の 結果, この最適解は施設番号 $108,134,148$ 救急告示 病院となった。ちなみに，これらの組み合わせは， Cグループの配置パターンに近く, 中心市街地の救 急告示病院 (107) が隣接する (108)に代わっている。 これらのカバー率は，71.2\%となりCグループより 1\%カバー率が向上しているに過ぎない。

\section{（2）施設の追加配置によるサービス水準の確保}

既存の救急告示病院の最適配置を考えても, $71.2 \%$ 地域をカバーしているにすぎない。また， 最適配置の場合でも，消防署から交差点に駆けつけ るまでの時間が 15 分以上の交差点が 3 箇所あるこ とが分かった。そこで，消防署の追加配置と現在の 告示病院以外に新たな病院を追加配置することを考 える。ここで消防施設から現場到着時間の制約を考 える場合, 処置時間に 5 分要することを考慮すれば, 少なくとも 10 分以内に駆けつけなくてはならない。 そこで, 制約時間 Sを 7 〜 10 分として, LSCP として 定式化し消防施設の配置問題を解いた。その結果を 表 5 に示す。これより，現在の消防施設数 7 に対し て，1〜3の施設の追加が必要となる。つぎに，各 追加配置施設の基で，搬送制約時間を 15 分として LSCP を用いて，C，Gグループについて救急告示病 院の追加配置を算定した。その結果を, 表 6 に示す。 これらより,救急告示病院側でも 10〜14 の施設の追 加配置が必要となる結果となった。

\section{表 5 消防署の配置数}

\begin{tabular}{|c|c|}
\hline 所要時間(分) & $\begin{array}{c}\text { 新たに立地した } \\
\text { 消防署数(個) }\end{array}$ \\
\hline 10分以内 & 1 \\
9分以内 & 2 \\
8分以内 & 3 \\
7分以内 & 3 \\
\hline
\end{tabular}


表 6 救急告示病院の配置数

\begin{tabular}{|c|c|c|}
\hline \multirow[t]{2}{*}{ 消防署数（個） } & \multicolumn{2}{|c|}{ 救急病院 数(個) } \\
\hline & cグループ & Gグループ \\
\hline $8(+1)$ & 14 & 13 \\
\hline $9(+2)$ & 11 & 12 \\
\hline $10(+3)$ & 11 & 11 \\
\hline $10(+3)$ & 10 & 10 \\
\hline
\end{tabular}

\section{4. 走行性向上によるサービス水準の確保}

3.では，施設配置の視点から，救急医療サービ スの確保について検討を試みた。しかし，市域全体 の救急医療サービスの水準を確保するためには，消 防署を含めた多くの救急医療施設を配置しなければ ならないことが明らかになった。しかし，現実的に， それだけの施設を配置することは不可能であろう。 そこで，救急車をスムーズに走行可能な施策（救急 車両通過掲示板の設置や，交差点信号の連動制御） を行い，救急車の走行パフォーマンスを確保した場 合のサービス水準について検討を試みる。

(a) 消防施設近傍のボトルネックとなるリンク の走行性の改善（16 本のリンクの現状値から $40 \mathrm{~km} / \mathrm{h}$ )

(b) 韹ットワーク全体の走行性の改善

（現状値の 20\%up）

まず(a)のケースについては, 平均搬送時間に対す る影響はほとんど見られない結果となった。消防施 設近傍のリンクの走行パフォーマンスをあげるだけ では，地域全体のサービス水準を確保できないこと がわかった。つぎに，(b)のケースの算定結果を表 7 に示す。表より，救急車の走行速度が $20 \%$ 向上する と, $\mathrm{C}$ グループでは 1 分 24 秒, $\mathrm{G}$ グループでは 1 分 48 秒平均搬送時間が短縮される結果となった。カバ 一率をみても，C グループでは 9\%up (79\%)， G グルー プでは 11\%up (58\%) となった。この結果より, 走行パ フォーマンスの確保と施設の配置の両方からの改善 が重要であると言えよう。

表 7 走行性向上によるサービスの変化

\begin{tabular}{|c|r|r|c|}
\hline \multirow{2}{*}{ グループ } & \multicolumn{2}{|c|}{ 平均搬送時間(分) } & カパー率 \\
\cline { 2 - 3 } & 変更前 & 変更後 & の変化 \\
\hline $\mathrm{C}$ & 13.5 & 12.1 & $9 \%$ \\
$\mathrm{G}$ & 16.0 & 14.2 & $11 \%$ \\
\hline
\end{tabular}

\section{5. 既存救急病院の追加指定とサービス水準の評価}

4.の算定事例より，救急車の走行時間を渋滞時 の車両実走時間で与えた場合, 市内全域において 15 分のサービス水準を確保するためには，新たな消防 署と既存救急病院以外の施設の配置が必要となる可 能性があることが分かった。しかし，現実的にその ような配置を行うことは，財政的にも困難である。 そこで，既存救急病院の最適配置（指定頻度を変化 させる）によるサービス水準の向上について考察す る。まず, 現在の既存救急病院を 1 グループ当たり， 2 から 5 に変化させた場合の最適施設配置と平均搬 送時間について算定を行った。その結果を図 9 に示 す。既存施設において，3施設以上を指定すれば平 均搬送時間は大幅に低減している。施設配置場所に ついては, 2 個の場合, 市内中心部と, 北東方面に, 3 個の場合，南西方面に追加され，4 個の場合，同 じく南西方面に追加，5個の場合西方面に追加とい う結果となった。しかし，既存の指定病院を効率よ く運用し，サービス水準を確保するためには，現在 以上の回数の指定を行い，1 週間のグループにおけ る最適配置を考えなければならない。

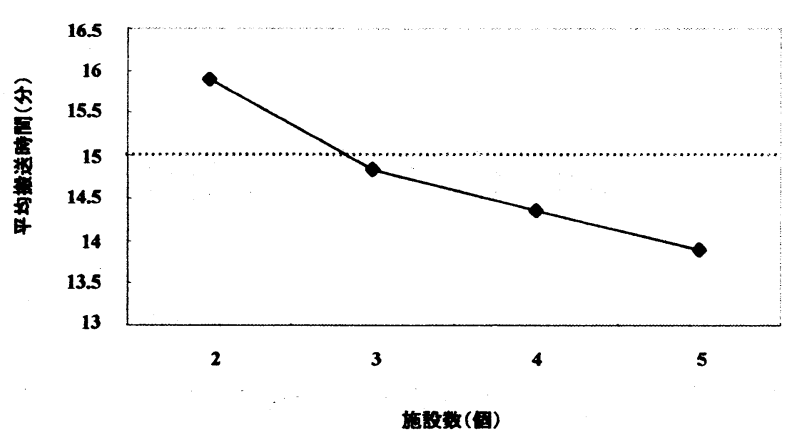

図 9 既存救急病院の最適配置 による平均搬送時間変化

\section{6. おわりに}

本研究では, 松山市内を対象として 15 分以内に救 急告示病院への搬送を確保することを救急医療サ一 ビス水淮と定義し，現状の運行体制と問題点を指摘 した。その結果, グループ単位で運用される救急告 示病院の配置とサービス水準に大きな較差があるこ とが明らかになった。最もサービス水準が高いグル 
ープでは, 70\%の交差点をカバーするが, 逆に最もサ 一ビス水準が低いグループでは $47 \%$ のカバー率に 過ぎないことが明らかになった。つぎに，松山市の 事故発生場所を GIS 上に表示した結果，80\%強の事 故が想定したネットワーク上で発生しており，かつ 比較的交差点付近に位置するため, それらを交差点 へ集約し各交差点に事故確率を与えた。これらの值 を用いて, サービス水準の評価を行った結果, カバ 一率の最も高いグループの平均搬送時間が 15.0 分 となり, 最もサービス水準が高い結果となった。し かし, 15 分以内の搬送時間を全域で確保する制約下 で LSCP を用いて施設配置問題を解いた結果, 消防署 施設も含めて, 13〜15もの新たな施設の配置が必要 となることを示した。また, 救急車両の走行パフォ ーマンスを確保すれば，現状の施設数でも市域全体 の救急医療サービスの水準を高めることを定量的に 示した。

今後の課題として，1つは，想定したネットワー クの再検討が上げられる。これは，松山市の事故発 生場所の空間分布に着目すると, ネットワーク以外 の細街路に集中する地域が見られることと，環状線 外域のリンク長が内部と比較すると長いため, 交差 点に交通事故を集約すると, 詳細な分析には不都合 である。そこで, 事故発生場所のデータを追加し, 事故発生の空間分布を詳細に分析し, ネットワーク を精緻化するとともに，リンク長を細分化する必要 があろう。2つは, 救急車両の走行に関する知見の 整理である。著者らは, 救急車両の速度を, 渋滞時 の車両速度として与えたが, 救急車両の走行実態調 査を行い, 時間帯や道路の形状 (車線数, 分離帯の 有無）など実走速度に影響を与える要因の分析と， 走行誘導型のシステム導入に伴う問題点の検討を試 みたいと考えている。また, 救急告示病院のグルー プについて，公平な分担のもとでグループ全体の最 適サービス水準を確保する配置についての検討も行 う必要があろう。そして, 上述した救急告示病院の 最適配置と，誘導型搬送システムを連動することに より,より高いサービス水準の確保が保証されよう。

\section{〈参考文献〉}

1) 大山達雄監訳 : 公共政策 $O R$ ハンドブック, 朝倉 書店, 1998.

2) NHK スペシャル「死者半減 西ドイツはこうして 成功した一第二次交通戦争への処方せん一」, NHK 出版, 1989.

3）松山市消防局: 消防年報（平成 9 年度版)，1998.

4) 日本建築学会編 : 建築・都市計画のためのモデル 分析の手法, 井上書院, 1992.

5)二神透, 大野訓, 柏谷増男, 荒川昌子 : 松山市の 交通事故における救急医療サービスの評価と施設 配置計画, 土木学会四国支部第 5 回究技術研究発 表会講演概要集, pp. 240-241, 1999.

6) Paul J. Densham, Gerard Rushton:A MORE EFFICIENT HEURISTIC FOR SOLVING LARGE P-MEDIAN PROBLEMS, PAPERS IN REGIONAL SCIENCE, pp. 307-329, 1992. 
交通事故に着目した救急医療サービスの評価に関する基礎的研究

二神 透, 大野 訓, 柏谷 増男

本研究では, 松山市域の交通事故を対象に, 救急医療サービスについての現状分析を行 った。その結果, 曜日単位のユニットで指定されている救急告示病院のサービス水準には 大きな差異があることや，搬送時間の公平性を確保するためには消防施設の新たな配置を 考慮しなければならないことを示唆することができた。さらに, 交通事故データをもとに, GIS を用いて事故の時空間分布を明示するとともに, 事故確率を考慮した救急医療施設配 置について言及した。最後に, 救急車の道路走行性の改善とサービス水準の関倸について, 若干の考察を行った。

A Study on Evaluation of Emergency Medical Service considering Traffic Accidents Tohru FUTAGAMI, Jun 00NO, Masuo KASHIWADANI

In this paper, we try to analyze the state of emergency service, especially considering traffic accidents in Matsuyama City. Because, it is indispensable for a victim who was seriously injured, must be conveyed more rapidly to an emergency hospital. Firstly, we analyze the service level of daily unit of emergency hospitals by Maximal Covering Location Problem. In the result, we make clear differences of their service levels, and some new fire stations are required to secure carrying time in the city. Secondly, we utilize GIS to grasp the spatial distribution of these accidental frequency, and analyze the emergency hospital location problem considering the probability of traffic accidents. Lastly, we refer to the relationship between the improvement of traveling performance of the ambulances on the current road network and the service level. 